\title{
Etos Kerja Wanita Pedagang Acung dan KebertahananNilai-Nilai Sosial-Ritual di Kalangan Masyarakat Bali
}

\author{
Desak Putu Parmiti \\ Teknologi Pendidikan, Fakultas Ilmu Pendidikan, Universitas Pendidikan Ganesha, Indonesia
}

\section{Keywords:}

ethos work;

free-merchant woman;

socio-culture value

\begin{abstract}
Target of this research is to identify and formulate of free-merchant woman work ethos at central of tourism area in Bali and to know relation among ethos work of free-merchant woman with socio-culture conflict. This Research used approach "Critical Etnography Research" in research paradigm qualitative. Research data collected by using partisipative observation, interview, quitionaire, and document studies. Overall of research data analysed by using technique analyse qualitative with analysis model pass by dots-quickly. Result of research indicate that: (1) all of free-merchant woman in Bali have typical of activity ethos and have the open character, (2) there are bearing having the character of magic-logical among ethos work of all free-merchant woman in Bali with friction of local socio-culrure, (3) patterned thinking and behavior of all free-merchants woman give very positive contribution to construction effort and added values for existention of Balines society.
\end{abstract}

\begin{abstract}
Abstrak:Tujuan penelitian ini adalah untuk mengidentifikasi dan memformulasikan etos kerja pedagang acung perempuan di kawasan sentrral kunjungan wisata di Bali dan untuk mengetahui hubungan antara etos kerja pedagang acung perempuan di kawasan sentral kunjungan wisata di Bali dengan perubahan dan konflik sosial-kultural. Penelitian ini menggunakan pendekatan "Critical Etnography Research" dalam paradigma penelitian kualitatif. Data penelitian dikumpulkan dengan menggunakan observasi partisipatif, wawancara, kuisioner, dan pencatatan okumen. Keseluruhan data penelitian dianalisis dengan menggunakan teknik analisis kualitatif dengan model analisis lintas situs. Hasil penelitian menunjukkan bahwa: (1) para pedagang acung perempuan di Bali memiliki etos kerja yang khas dan bersifat terbuka, (2) terdapat kaitan yang bersifat logis-magis antara etos kerja para pedagang acung perempuan di Bali dengan pergeseran nilai-nilai sosio-kultural pada masyarakat setempat, (3) pola pikir dan perilaku para pedagang acung perempuan di Bali memberikan kontribusi yang sangat positif bagi upaya pembinaan dan kebertahanan nilai-nilai adat istiadat masyarakat Bali.
\end{abstract}

\section{Alamat Korespondensi:}

E-mail: dp-parmiti@undiksha.ac.id (Desak Putu Parmiti)

\section{Pendahuluan}

Bali sebagai komunitas masyarakat yang unik, pada dasarnya sama dengan masyarakat lainnya yang sedang mengalami perubahan sosial dan transisi budaya. Mengantisipasi berbagai kemungkinan yang akan terjadi, pembinaan dan pendayagunaan desa-desa adat dengan segala dimensinya yang ada di Bali saat ini sedang diintensifkan. Pembinaan diarahkan pada upaya perumusan dan mempertahankan nilai-nilai adat dan budaya masyarakat setempat.Salah satu masalah yang berkembang dan dihadapi oleh masyarakat Bali saat ini adalah mengenai penataan etika moral keagamaan di kalangan pelaku in dustri pariwisata, yang tersebar di berbagai desa adat di Bali.Saat ini masyarakat Bali merupakan salah satu masyarakat yang sedang mengalami transisi.Kalangan budayawan dan pakar ilmu sosial memandang masyarakat Bali yang sedang mengalami transisi dihadapkan pada dualisme kehidupan sosial dan budaya yang sangat tajam, hal mana merupakan ciri dari masyarakat yang sedang mengalami masa transisi.

Kondisi ini membawa konsekuensi yang sangat mendasar bagi kehidupan dan upaya mempertahankan kemurnian adat istiadat masyarakat desa adat yang telah terpelihara ratusan tahun, sehingga konflik sosial diantara masyarakat desa adat tidak dapat dihindarkan, seperti halnya sengketa ekternal maupun internal sehubungan dengan ikatan adat istiadat yang sedang marak di berbagai daerah 
di Bali saat ini. Mempelajari dan mengakaji dinamika sengketa sosial dan budaya yang terjadi pada masyarakat desa adat Bali saat ini memiliki makna yang sangat strategis bagi upaya pengembangan dan pembinaan serta mempertahankan nilai-nilai budaya masyarakat Bali yang sangat tinggi nilainya, dan memformulasikan kaitan etos kerja para pedagang acung perempuan dengan upaya mempertahankan nilai-nilai adat istiadat pada khususnya. Croch seorang pemerhati kebudayaan Bali dalam disertasinya memaparkan dengan gamblang tentang konflik sosial-kultural yang terjadi di kalangan masyarakat Bali timur, yang dikutif oleh Nesta (1998), bahwa" secara empiris saat ini masyarakat Bali di bagian timur mengalami degradasi nilai-nilai sosial-kultural yang disinyalir disebabkan oleh pengembangan industri pariwisata, terutama pada kalangan perempuan pelaku pariwisata, sehingga tidak jarang konflik sosial itu dipicu oleh seorang perempuan"...kondisi masyarakat Bali timur saat ini bisa disamakan dengan nelayan di tengah samudra dengan hasil tangkapan ikan yang sangat banyak namun tiang layar perahunya patah,...". Berdasarkan kondisi tersebut, maka penelitian ini tampaknya memiliki nilai strategis yang sangat mendasar sehubungan dengan upaya pengembangan dan pembinaan nilai-nilai budaya dan adat istiadat di kalangan perempuan pada masyarakat desa adat Bali. Melalui penelitian ini akan dapat dimengerti kaitan dan jaringan antara "social action" dan "social objectives", serta "subjective experiences" masyarakat dalam hubungannya dengan etos kerja pedagang acung perempuan sebagai salah satu penunjang industri kepariwisataan dan kaitannya dengan upaya mempertahankan serta membina nilai-nilai adat istiadat masyarakat Bali secara komprehensif, bermakna, dan holistik.

Para pedagang acung perempuan, dalam aktivitas kesehariannya selalu bergaul dengan para wisatawan, baik domestik maupun internasional, dimana budaya dari mereka sangat berbeda dengan budaya Bali.Kontak yang terjadi diantara mereka, tidak jarang mempengaruhi pola perilaku dan pola pikir di kalangan para pedagang acung perempuan.Hal ini penting, mengingat para pedagang acung tersebut harus memahami sedikit tidaknya pola pikir dan perilaku para wisatawan, demi keberhasilan usahanya. Di sisi lain, dalam lingkungan masyarakat desa adatnya, para perempuan ini harus memerankan dirinya sebagai wanita Bali, yang bertugas dan berfungsi sebagai pendamping suami dan menjaga anak-anaknya, sambil melaksanakan aktivitas keagamaan bersendikan nilai-nilai agama Hindu, yang senantiasa kaya akan upacara-upacara ritual, yang menekankan pada aspek kesucian. Dilematisasi di atas, tampaknya sangat strategis untuk dikaji lebih jauh, mengingat saat ini, beberapa konflik sosial-kultural yang terjadi di Bali, tidak jarang dipicu oleh pola perilaku dan sikap yang dipandang bertentangan atau tidak sesuai dengan nilai-nilai adat istiadat masyarakat Bali, dimana di dalamnya termasuk kalangan perempuan.

Berdasarkan kajian empiris di atas, maka penelitian ini akan diarahkan pada upaya penggalian yang mendalam terhadap etos kerja pedagang acung perempuan di kawasan sentral kunjungan wisata di Bali, dan hubungannya dengan perubahan sosial-kultural di kalangan masyarakat adat Bali. Di samping itu, melalui penelitian ini juga akan dicoba untuk menemukan dan memformulasikan profil perempuan Bali dalam dinamisasi masyarakat Bali sebagai dampak dari pengembangan industri pariwisata. Untuk itu, pendekatan yang digunakan dalam penelitian lebih mendekati penelitian etnography research, dengan menjadikan para pedagang acung perempuan di sentral kunjungan wisata di Bali sebagai responden penelitian. Berdasarkan latar belakang di atas, maka permasalahan pokok yang ingin dicari jawabannya dalam penelitian ini adalah "bagaimanakah etos kerja pedagang acung perempuan di kawasan sentral kunjungan wisata di Bali, dan bagaimana kaitan logis antara etos kerja pedagang acung perempuan terhadap konflik sosial-kultural di kalangan masyarakat Bali ?". Sementara tujuan yang ingin dicapai dalam penelitian ini pada dasarnya adalah: "untuk mengidentifikasi dan memformulasikan etos kerja pedagang acung perempuan di kawasan sentrral kunjungan wisata di Bali, dan untuk mengetahui hubungan antara etos kerja pedagang acung perempuan di kawasan sentral kunjungan wisata di Bali dengan perubahan dan konflik sosial-kultural yang terjadi pada masyarakat adat di Bali".

Penelitian ini diharapkan memberikan manfaat baik secara praktis maupun teoritis, sebagai berikut: (1) bagi pengambil kebijakan yang terkait dengan pembinaan dan pengembangan nilai-nilai adat istiadat di Bali khususnya dan pembangunan masyarakat dan budaya Bali pada umumnya dapat memanfaatkan temuan penelitian ini, mengenai pentingnya pemahaman terhadap etos kerja pedagang acung perempuan sebagai dasar pembinaan dan pelestarian nilai-nilai adat istiadat masyarakat adat Bali, khususnya bagi para perempuan pelaku industri kepariwisataan yang tersebar di berbagai daerah di Bali, dan (2) dapat memberikan sumbangan pengetahuan sosio-kultural tentang profil pedagang acung perempuan pada kawasan sentral kunjungan wisata di Bali dan kaitan logis antara etos kerja pedagang acung perempuan dengan perubahan serta konflik sosial-kultural yang terjadi di kalangan masyarakat adat di Bali. 


\section{Metode}

Penelitian ini dilihat dari pendekatannya menggunakan pendekatan "Critical Etnography Research" dalam paradigma penelitian kualitatif (Anderson, 1989) yang mengedepankan reset sosial sebagai bentuk kritik sosial dan budaya masyarakat (Miles dan Huberman, 1992). Melalui pendekatan ini akan dibentuk relasi sistem dengan menggunakan kekuatan menganalisis dan mensintesis keterkaitan antara tindakan, pengalaman subjektif, dan kondisi sosial yang terkait langsung dengan permasalahan penelitian yaitu etos kerja pedagang acung perempuan dalam suatu deskripsi dan narasi yang aktual, komprehensif, kontekstual, holistik, dan bermakna. Penelitian ini akan dilakukan di kawasan sentral kunjungan wisata yang tersebar di Provinsi Bali, yang mencerminkan tingkat perkembangan masyarakat desa adat Bali, yaitu: Kuta, Sanur, Nusa Dua, Ubud, Tampaksiring, Kintamani, Besakih, dan Lovina Buleleng. Dalam penelitian ini, subjek penelitian atau responden ditentukan secara bertujuan (pusposive sampling technique) dan akan dikembangkan melalui snowball sampling. Besaran jumlah subjek penelitian tidak dapat ditentukan sebelumnya, karena sangat tergantung pada tingkat kejenuhan data yang diperlukan selama penelitian. Untuk kepentingan validasi data, maka peneliti juga akan melibatkan beberapa pakar dibidangnya sesuai dengan fokus penelitian, dan beberapa catatan dokumen adat serta beberapa dokumen resmis yang berkaitan dengan data yang diperlukan selama penelitian.

Sesuai dengan jenis data yang diperlukan dalam penelitian ini, maka pengumpulan data penelitian ini menganut prinsip "peneliti adalah instrumen penelitian yang utama". Namun dalam pelaksanaannya, peneliti juga akan menggunakan beberapa alat pengumpul data, yaitu: (1) wawancara mendalam, (2) observasi yang Intensif dan Kausal, (3) enyebaran Kuisioner, dan (4) pencatatan dokumen. Sesuai dengan jenis pendekatan dan karakteristik penelitian, maka analisis datanya akan dilakukan secara terus menerus dari awal hingga akhir keseluruhan penelitian. Pada tahap ini, data yang terkumpul akan disusun, digolongkan kedalam katagori, konsep, proposisi, pola atau tema-tema budaya tertentu (Spradley, 1997). Setelah itu akan dilakukan interpretasi terhadap keseluruhan data, yakni dengan memberi makna dan menjelaskan katagori, pola dan mencari keterkaitan antara berbagai konsep dan proposisi. Proses analisis seperti itu, memprasyaratkan analisis data dilakukan secara siklus, bukan secara linier (Miles dan Huberman, 1992) Proses tersebut sering disebut dengan "siklus interaktif".

\section{Hasil dan Pembahasan}

\section{Hasil Penelitian}

\section{a. Etos Kerja Pedagang Acung Wanita dan Perubahan Sosio-Kultural}

Berdasarkan analisis data yang dikumpulkan melalui observasi, wawancara, dan penyebaran kuisioner dapat diformulasikan secara singkat mengenai hubungan etos kerja dengan perubahan sosialkultural di kalangan pedagang acung wanita Bali di daerah-daerah kunjungan wisata sebagai berikut. Bahwa etos kerja para pedagang acung wanita bali sangat tinggi dan disiplin yang dibalut oleh pernikpernik nilai sosial-kultural yang sangat tajam. Penajaman dalam dimensi nilai sosial-kultural ini disebabkan oleh lingkungan tempat tinggal dan penanaman nilai sejak dini di kalangan wanita bali, baik yang melalui pendidikan keluarga, non-formal, maupun pendidikan formal. Wanita bali pada umumnya telah dikenalkan pada nilai-nilai sosial-kultural sedini mungkin oleh keluarganya dan diiringi dengan praktek dalam kehidupan masyarakat tempat tinggalnya. Berdasarkan gambaran di atas tampak bahwa ada kaitan logis antara perubahan nilai sosial-kultural dengan etos kerja para pedagang acung wanita.Pola pendidikan dan warna nilai sosial-kultural yang senantiasa menghiasi setiap gerak dari kaum wanita di Bali. Di sisi lain, dengan aktivitas dan pola kerja yang bersifat terbuka dalam menjalankan profesinya sebagai pedagang acung, dewasa ini di kalangan masyarakat Bali, khususnya di daerah-daerah kunjungan wisata telah terjadi perubahan sosio-kultural yang bersifat terbuka. Berdasarkan jawaban kuisioner responden dan didukung oleh hasil wawancara, terungkap bahwa di kalangan wanita pedagang acung wanita di Bali telah terjadi modernisasi pola pikir dan perilaku yang signifikan.Dilihat dari kaitan logis antara aspek politis ekonomi, tampak bahwa kaum wanita yang berprofesi sebagai pedagang acung memiliki etos kerja yang jauh lebih produktif dan terbuka dibandingkan dengan kaum wanita lainnya secara umum.Perubahan etos kerja ini diiringi dengan terjadinya perubahan pada emansipasi dan partisipasi mereka dalam kehidupan sosial-budaya di masyarakatnya.Hal ini menunjukkan bahwa telah terjadi perubahan sosio-kultural dalam kehidupan masyarakat desa di lingkungan industri pariwisata seiring dengan terjadinya perubahan etos kerja kaum wanita di desa setempat.Makna yang terungkap dari preposisi ini adalah ada hubungan yang signifikan antara etos kerja wanita dengan perubahan sosiokultural pada suatu masyarakat industri di bidang pariwisata.Realitas dan kecendrungan tentang peran 
dan status wanita dalam kehidupan keluarga maupun masyarakat sebagaimana yang terurai di atas menurut teori fungsional struktural adalah merupakan sebuah kebenaran yang menggejala.

\section{b. Hubungan Etos Kerja dengan Perubahan Sosio-Kultural Masyarakat}

Berdasarkan observasi dan wawancara yang dilakukan terhadap responden, maka dapat dideskripsikan secara aktual dan sistimatis mengenai etos kerja pedagang acung wanita di kawasan sentral kunjungan wisata di Provinsi Bali, sebagai berikut.Para pedagang acung pada umumnya berasal dari desa-desa yang ada di sekitar daerah wisata bersangkutan. Aktivitas "berdagang" yang dilakukan akan dimulai pada saat mereka telah merampungkan keseluruhan tugas-tugas rumah tangga, seperti memasak, membersihkan rumah, menghaturkan sesajen, dan menyiapkan makanan bagi anggota keluarga lainnya. Pada umumnya, mereka akan memualai menjajakan dagangannya antara pukul $11.00-13.00$ WITA dan mengakhirinya pada saat para turis (tamu yang ada di objek wisata) pulang dan lokasi mulai beranjak sepi, yaitu antara pukul $16.00-17.00$ WITA.

Jenis barang dagangan yang biasanya dijual adalah patung kayu, topeng kayu, souvenir, kain, selendang, dan pakaian pantai.Pola perilaku para pedagang acung ini, tidak jauh dari pola perilaku para pedagang di beberapa pasar tradisional umumnya. Namun yang menjolok adalah bahwa para pedagang acung ini lebih agresif dan cekatan dalam memikat pelanggan dengan kata-kata bahasa tertentu (inggis, china, Korea, ataupun Indonesia) dengan nada yang sedikit "merayu". Para pedagang acung ini akan duduk ataupun berdiri dengan barang dagangannya di tempat-tempat yang strategis, yaitu di tempat para tamu/turis biasanya ramai. Aktivitas (pola perilaku dan ucapan) para pedagang acung ini di tempat objek wisata biasanya berbeda dengan pola perilaku atau tutur kata mereka pada saat mereka telah kembali ke rumahnya masing-masing. Ketika mereka ada di rumah, para pedagang acung ini secara umum akan kembali menjadi ibu dan istri yang bertautkan nilai-nilai sosial-budaya Bali yang kental. Profesi dagang acung ini dilakukan oleh para wanita Bali, ternyata tidak semata-mata disebabkan oleh desakan faktor ekonomi. Hal ini terungkap dari observasi dan wawancara dengan beberapa responden, bahwa mereka melakukan pekerjaan ini disebabkan oleh beberapa faktor selain faktor ekonomi, antara lain: hobi, emansipasi, dan partisipasi. Dilihat dari latar belakang pendidikan para pedagang acung wanita ini, ternyata 86,5 \% adalah tamatan sekolah dasar dan tidak tamat sekolah dasar, 7,5 \% tamatan SLTP, 5 \% tamatan SMU/SMK, dan 3 \% tidak pernah sekolah. Namun yang cukup ekslusif adalah tidak adanya perbedaan yang menjolok dalam kemampuan dan keterampilan mereka berbahasa Indonesia ataupun melafalkan bahasa asing.Hal ini menunjukkan bahwa latar belakang pendidikan tidak terlalu berpengaruh terhadap kinerja pedagang acung wanita yang ada di Bali.Hal menarik lainnya adalah para pedagang acung ini tidak atau jarang sekali menggunakan kemampuan dan keterampilan berbahasanya ini di dalam kehidupan rumah tangganya. Di sisi lain, tampak pula profesi pedagang acung ini tidak semata-mata didorong oleh faktor ekonomi, namun sudah masuk faktor emansipasi dan partisipasi. Hal ini menunjukkan bahwa wanita bali adalah wanita yang tidak senang dimanja dan mengeksploitasi suami. Mereka akan tergerak hati dan perasaannya sedemikian rupa bilamana melihat dan merasakan ketidakharmonisan ataupun dinamika baru di lingkungan tempat tinggalnya. Realitas ini mengindikasikan bahwa wanita bali adalah sosok pekerja keras yang menjungjung tinggi nilai-nilai agama dan budayanya.

\section{c. Pola Pikir dan Perilaku Pedagang Acung Perempuan dan Upaya Pembinaan dan Kebertahanan Adat Istiadat Masyarakat}

Berdasarkan temuan di lapangan, tampak bahwa kalangan pedagang acung perempuan memiliki perilaku yang rada-rada sama dengan kaum perempuan lainnya di Bali. Hal ini ditunjang oleh bukti di lapangan yang menunjukkan bahwa mereka tidak menampakkan perilaku yang eksklusif di tengah-tengah masyarakat. Para pedagang acung perempuan dalam kehidupan sehari-harinya senantiasa mengikuti pola dan norma-norma sosial yang telah diakui dan ditaati oleh semua anggota masyarakatnya. Menurut mereka, yang sedikit berubah pada dirinya adalah keterbukaan dan keluasan cara berpikirnya. Jika sebelum melakoni kehidupan sebagai pedagang acung, mereka cenderung terpaku pada pola pikir wanita Bali pada umumnya, yaitu penurut, santun, pekerja keras, bakti pada suami, pasrah, dan transendental, maka setelah mereka menjalani profesi sebagai pedagang acung, dimana mereka bergaul dan berinteraksi dengan berbagai ragam masyarakat dan golongan para wisatawan mancanegara, pola pikirnya menjadi lebih terbuka dan cenderung demokratis. Dalam tataran kehidupan masyarakat, peran dan fungsi wanita sebagai pendukung utama kehidupan rumah tangga tidak bisa diabaikan begitu saja.Melalui peran dan fungsi yang dijalankannya, kaum wanita telah mampu menampakkan dirinya sebagai sebuah kekuatan riil dalam kehidupan bermasyarakat, berbangsa dan bernegara. Wanita merupakan pilar pembangunan yang cenderung dikorbankan dan mengorbankan diri bagi kemajuan bangsa dan negerinya, khususnya yang berkaitan dengan aspek-aspek sosial budaya yang cenderung mengikat keseharian mereka. 
Di sisi lain eksistensi dan partisipasi para pedagang acung perempuan dalam kehidupan masyarakatnya cenderung meningkat. Hal ini tidak terlepas dari keterbukaan mereka dalam berperilaku dan berpikir, sehingga dalam dimensi kehidupan masyarakat tertentu mereka dapat berpartisipasi secara lebih intens, seperti: dalam pertemuan muda-mudi (bagi pedagang acung yang masih lajang), organisasi PKK desa, organisasi sosial-keagamaan, dan kegiatan-kegiatan ritual yang dilaksanakan di masyarakatnya. Peningkatan partisipasi ini banyak dikontribusi oleh status ekonomi dari para pedagang acung perempuan itu sendiri. Di sisi lain, peningkatan pengetahuan dan cara berpikir para pedagang acung ini telah menyebabkan mereka lebih mudah dalam memahami aturan-aturan adat istiadat masyarakatnya, termasuk berbagai tata peraturan yang diterbitkan oleh pemerintahan formal.

\section{d. Modernitas Pedagang Acung Perempuan pada Kawasan Sentral Kunjungan Wisata di Bali}

Berdasarkan wawancara dan observasi yang dilakukan terhadap responden, maka dapat diidentifikasi beberapa komponen dimensi modernitas dari para pedagang acung perempuan Bali, yang meliputi: (1) sikap dan perilaku, (2) tata busana, (3) hubungan sosial, (4) orientasi nilai diri, (5) orientasi nilai sosial, (6) keterikatan sosial-budaya, (7) kepatuhan terhadap nilai-nilai budaya, (8) nilai religiusitas, dan (9) orientasi kehidupan material. Dilihat dari sikap dan perilaku para pedagang acung dalam kehidupannya sehari-hari, dapat diidentifikasi bahwa secara umum mereka senantiasa bersikap dan berperilaku bersandarkan pada nilai dan tata aturan adat istiadat masyarakatnya.

Dalam berperilaku, baik dalam kehidupannya sehari-hari maupun saat menjalankan profesinya sebagai pedagang acung, mereka selalu memperhatikan dan mentaati norma-norma sosial yang telah ditetapkan oleh desa adatnya. Dengan demikian, baik sikap dan perilakunya masih ada dalam koridor adat istiadat dan nilai-nilai kesopanan sosial.Menurut mereka, dalam berperilaku memang ada sedikit keterbukaan dibandingkan dengan kaum perempuan lainnya. Hal ini disebabkan karena seringnya mereka bergaul dan berinteraksi dengan orang "luar", sehingga mereka secara tidak langsung telah "terkontaminasi" tentang tata cara dan sikap pergaulan sehari-hari. Perubahan ini, menurut mereka adalah hal yang wajar dan masih ada dalam batas-batas kesopanan dan nilai adat istiadatnya.Bagi mereka, berubah itu adalah hal yang wajar dan harus, yang penting masih dibenarkan oleh adat dan norma-norma kesopanan yang berlaku pada masyarakatnya. Dilihat dari tata cara dan model berpakaian dan pengenaan aksesoris, menurut sebagian besar responden diperoleh data bahwa tata cara dan model pakaian yang mereka kenakan masih mengikuti tata berbusana masyarakat dimana mereka hidup. Walupun untuk acara atau kesempatan tertentu mereka tampak menonjol dalam tata busana dan model tampilan diri, itu lebih disebabkan karena mereka telah mengenal dan melihat tata berbusana dan model pakaian yang lebih banyak dibandingkan dengan perempuan lainnya. Hal itu tidak bisa dilepaskan dari profesi mereka sebagai pedagang acung, yang selalu berinteraksi dengan kalangan wisatawan dari berbagai penjuru dunia, dengan model dan tata busana yang diferentiatif.Artinya bahwa tata busana dan model pakaian mereka lebih modern dibandingkan dengan kaum perempaun pada umumnya, tetapi masih dalam taraf kewajaran dilihat dari nilai dan aturan adat istiadat masyarakatnya.

Dilihat dari orientasi nilai diri, para pedagang acung perempuan di Bali memiliki orientasi nilai yang cukup maju.Bagi mereka, perubahan masyarakat tidak harus dihindari atau hanya menerima segalanya dengan berdiam diri.Mereka melakoni pekerjaan berdagang acung justru dimaksudkan untuk mengenal dunia luar dengan lebih baik dan dapat bergaul dengan orang-orang dari berbagai belahan dunia, disamping karena hobi, kebutuhan ekonomi, dan sebagai wujud emansipasi serta tanggungjawab diri sebagai bagian dari sebuah keluarga.

\section{Pembahasan}

Para pedagang acung perempuan sebagai bagian integral dari perempuan Bali sebagai warga desa adat dan warga masyarakat pada umumnya, secara humanistis tidak jauh berbeda dengan perempuan pada masyarakat lainnya, khususnya pada masyarakat Indonesia.Kekhususan yang tampak pada perempuan Bali lebih mengacu pada keterikatan sosial-budaya, khususnya adat istiadat masyarakatnya, yang unik dan memiliki karateristik eksklusif yang membedakannya dengan masyarakat Indonesia pada umumnya.Dilihat dari perspektif politis, perempuan Bali memiliki eksistensi yang sangat kuat, khususnya dalam tataran adat istiadat dan tata upacara keagamaan.Mereka memiliki peranan yang sangat penting dan menentukan dalam kegiatan-kegiatan adat istiadat dan upacara keagamaan.Hal ini tidak terlepas dari situs sosial-budaya masyarakat Bali itu sendiri.Eksistensi dan orientasi perempuan Bali mengenai masyarakat dan masa depannya tidak bisa dipisahkan dari latar sosial-budaya yang melekat dan telah menjadi potret hidup bagi anggota masyarakat Bali itu sendiri.

Dilihat dari dimensi politik, partisipasi perempuan Bali dalam aktivitas sosial-budaya, tampak bahwa hal tersebut lebih banyak berlangsung secara informal.Artinya, bahwa aktivitas mereka lebih banyak berlangsung di dalam lingkungan keluarga dan kehidupan masyarakat sehari-hari.Perilaku 
bermasyarakat yang senantiasa diharapkan oleh khalayak umum adalah bagaimana perilaku tersebut tetap bersandar kepada nilai-nilai budaya masyarakat itu sendiri.Hal ini sejalan dengan pandangan dan sikap para pedagang acung perempuan di Bali berkaitan dengan pola perilaku dan orientasi nilai yang mereka anut dan yakini dalam pergaulannya sehari-hari.Ada sejumlah orientasi dan visi kedepan perempuan Bali yang dapat peneliti formulasikan berdasarkan temuan di lapangan dan analisis kebutuhan menyangkut kesetaraan dan peran ganda di kalangan perempuan dan laki-laki yang diharapkan.Hal ini membuktikan bahwa, dilihat dari dimensi pendidikan dan kemampuan mengaktualisasikan diri, perempuan Bali cukup memiliki potensi untuk berperan serta secara sejajar dengan laki-laki. Mereka juga memiliki keinginan untuk mengembangkan pergaulan global, hal ini terlihat dari banyaknya perempuan Bali yang merantau, yaitu bekerja dan sekolah di luar lingkungan desanya. Hal ini merupakan salah satu implementasi nilai modernitas di kalangan perempuan Bali. Mereka (perempuan Bali) menginginkan adanya perlakuan dan peran yang sama dalam menentukan kebijakan keluarga, baik yang menyangkut perencanaan, pelaksanaan, dan menikmati hasil dari kebijakan itu sendiri. Mereka ingin bekerja secara bersama-sama dengan prinsip, "berat sama dipikul, dan ringan sama dijinjing".Hal ini terkait dengan konsep nilai budaya pungkusan yang begitu dipahami oleh angota masyarakat desa adat di Bali.Di samping itu, visi dan orientasi menyangkut pergaulan global (keterbukaan) merupakan salah satu indikasi bahwa perempuan Bali tidak tertutup terhadap masyarakat luar, termasuk terhadap akulturasi budaya. Dilihat dari gagasan dan orientasi dalam dimensi pemahaman dan ketaatan tehadap nilai-nilai dan norma adat istiadat tampak bahwa perempuan Bali menginginkan agar masalahmasalah adat dapat diselesaikan dalam lingkungan keluarga atau secara kekeluargaan. Lembaga adat dalam hal ini desa adat merupakan institusi sosial yang sangat dihormati sebagai sebuah lembaga yang dapat memberikan perlindungan hukum. Banyak masalah-masalah hukum cukup diselesaikan oleh desa adat, sehingga tidak sampai ke desa dinas atau lembaga-lembaga peradilan di atasnya.

Perempuan Bali termasuk di dalamnya pedagang acung perempuan sangat paham dengan perkembangan situasi masyarakat dewasa ini. Hal itu dapat dilihat dari pendapat dan pandangan mereka terhadap berbagai peristiwa di bebagai daerah yang mereka simak melalui pesawat TV atau radio, dimana mereka menyatakan kepihatinan dan protes terhadap berbagai kerusuhan dan tindakan anarkhi yang dilakukan oleh sekelompok orang untuk memaksakan kehendaknya. Indikasi dari hal ini adalah bahwa perempuan Bali memiliki sifat dan jiwa keadilan dan kemanusiaan yang universal. Universalitas sifat dan jiwa masyarakat merupakan salah satu indikator yang mendukung terbentuknya masyarakat demokrasi (Tilaar, 1999), karena universalitas akan membangun masyarakat menjadi profesional dan mandiri dalam menjalani berbagai dinamisasi zaman yang serba cepat. Disinilah makna dari etos kerja dari pedagang acung perempuan, yaitu menghiasi dinamika dan pola orientasi dari masyarakat Bali, khususnya kaum perempuan Bali secara umum.

\section{Simpulan}

Berdasarkan temuan penelitian di atas, maka ada sejumlah konsep dan generalisasi yang dapat diformulasikan sebagai simpulan dari penelitian ini, yaitu : (1) para pedagang acung perempuan di Bali memiliki etos kerja yang khas dan bersifat terbuka. Kekhasan tersebut tercermin dari pola dan strategi yang mereka lakukan dalam menjalani dan menyikapi berbagai phenomena yang dihadapi saat mereka melakukan aktivitas dagangnya, (2) terdapat kaitan yang bersifat logis-magis antara etos kerja para pedagang acung perempuan di Bali dengan pergeseran nilai-nilai sosio-kultural pada masyarakat setempat, (3) pola pikir dan perilaku para pedagang acung perempuan di Bali memberikan kontribusi yang sangat positif bagi upaya pembinaan dan kebertahanan nilai-nilai adat istiadat masyarakat Bali, dan mereka juga memiliki nilai modernitas yaitu telah mampu memformulasikan pola dan tatanan kehidupan yang ideal di masa depan bagi desa adatnya dan masyarakat Bali pada umumnya. Hal ini terjadi disebabkan oleh pergaulan dan keterbukaan cara berpikir dan berperilaku di kalangan pedagang acung yang kesehariannya senantiasa bergaul dengan berbagai karakteristik dan kebangsaan manusia dari berbagai penjuru dunia.

Etos kerja para pedagang acung perempuan di kawasan sentarl kunjungan wisata di Provinsi Bali memiliki prospek yang sangat menjanjikan dilihat dari dimensi ekonomis, untuk itu, maka upaya pembinaan dan pengembangan kemampuan dan keterampilan mereka harus mendapat perhatian dari berbagai kalangan, khususnya Dinas Pariwisata dan Dinas Pendapatan Daerah, sehingga kinerja mereka semakin meningkat dan akan menguntungkan secara finansial bagi pendapatan daerah. Di sisi lain, upaya pembinaan berkait dengan kebertahanan nilai-nilai sosial-budaya di kalangan para pedagang acung perempuan dan perempuan Bali pada umumnya, merupakan sesuatu yang sangat mendesak untuk dilakukan, mengingat dinamisasi masyarakat dan pengaruh budaya asing semakin menggejalan dan 
menyingkapkan berbagai tabir kemunafikan masyarakat modern. Dengan demikian, jika masyarakat Bali ingin tetap mempertahankan nilai dasar dari budaya dan adat istiadatnya, maka upaya pemagaran terhadap eksistensi kaum perempuan dalam kiprahnya di dunia modern adalah sesuatu yang sangat urgen dan strategis.

\section{Referensi}

Anderson, J. (1989). Qualitative Research: Introduction for Begginer. NY: McMilland, Co.

Carspecken, Phil Francis. (1996). Critical Ethnography in Educational Research: A Theoritical and Practical Guide. New York and Londen: Routledge.

Jacqueline Chabaud. (1984). Mendidik dan memajukan Wanita. Jakarta: PT. Gunung Agung.

Julia Cleve Mosse. (1996). Gender dan Pembangunan. Yogyakarta: Pustaka Pelajar.

Megawangi, R. (1999). Membiarkan Berbeda ?: Sudut Pandang Baru Tentang Relasi Gender.Bandung : Mizan.

Miles, Mathew B and A Michael Huberman. (1992). Qualitative Data Analysis: A Sources Book of New Method. London: Sage Publication.

Nesta.(1998). Masyarakat Bali dalam Kebalian yang Tersamarkan (Makalah). Denpasar: Dirjen Kebudayaan RI.

Suhartono.(1991). Apanage dan Bekel Perubahan Sosial di Pedesaan Surakarta 1830-1920. Yogyakarta: Gadjah Mada Universitas Press.

Spradley, J. P. (1997). Metode Etnografi. Pengantar Amri Marzali, PT. Tiara Wacana, Yogyakarta.

Tilaar.(1999). Paradigma Baru Pembangunan Masyarakat Pedesaan. Jakarta-Bandung: Pt. Rosdakarya Pratama.

Warren, Carol. (1991). "Adat and Dinas: Village and State in Contemporary Bali". Dalam Hildred Geertz (ed), State and society in Bali. Leiden : KLTLV Press.

Weck, Wolfgang. (1976). Heilkunde und Volkstum auf Bali. : P.T. Intermasa. 
8Jurnal Penelitian dan Pengembagan Sains dan Humaniora, Vol 1(1)April 2017, h. 1-7 